\title{
Sustainable Development and Landscape Protection in Low- Income Urban Coastal Areas: Empowerment Through Sovereignty and Deliberative Participation
}

\author{
Astrid Meilasari-Sugiana ${ }^{1 \star}$, Sandra Madonna ${ }^{1}$, Dianingtyas Putri ${ }^{1}$, Solikhah Solikhah ${ }^{2}$ \\ ${ }^{1}$ Bakrie University, Jakarta, Indonesia \\ ${ }^{2}$ Faculty of Public Health, Universitas Ahmad Dahlan, Yogyakarta, Indonesia \\ ${ }^{*}$ corresponding author, e-mail: astrid.sugiana@bakrie.ac.id
}

Received: 01/11/2020; published: 30/12/2020

\begin{abstract}
Background: The Government of Indonesia is currently implementing its Coastal Community Economic Empowerment Program or Pemberdayaan Ekonomi Masyarakat Pesisir (PEMP) to numerous coastal communities in the island of Java, Sumatra, Sulawesi, Kalimantan and Nusa Tenggara. The program is geared to empower local coastal communities through its integrated, holistic vision, its local-based, participatory method, and its public-partnership approach. Locality is important since the program aims to induce local initiatives and retain social and economic progress within the area, taking into account its ecological carrying capacity. Method: The research is a qualitative inquiry using ethnomethodological tools and purposive, snowball sampling. The research was conducted in 2015-2016 in Cilacap, Central Java. Data analysis was conducted through tabulation, categorization, comparison, conceptualization and theorization. Results: Issues beset the government's PEMP program, including its utilitarian framework to coastal resource governance, its adverse incorporation of small fishermen into the fishing industries, and its unsustainable public-private partnership to promote entrepreneurial growth. Attempts to resolve those issues include ensuring that funding for the PEMP program is incorporated within the yearly provincial and regency budgets and regulations, instilling consensus building over the program's direction and activities with local communities and the private sector through the Provincial and Regency Level People's Representative Council, and brokering with local communities and the private sector to achieve workable common ground should conflicts arise. Conclusion: Establishing sound intervention policies and programs require securing flexibility and adaptive management capacity through negotiations and brokering.
\end{abstract}

Keywords: coastal communities; empowerment; sustainable development; entrepreneurship; public-private partnership; sovereignty; deliberative participation

Copyright $\odot 2013$ Universitas Ahmad Dahlan. All rights reserved.

\section{Introduction}

In its endeavor to protect Indonesia's coastal resources, the government addresses the interrelatedness of ecosystems by integrating the various user groups and government departments in its policy and program planning and implementation. Collaboration and coordination mechanisms in the form of legislations, institutions and umbrella agencies are instituted to incorporate the diverse user groups and ensure the integrated management of coastal resources. The impacts of development activities on the country's coastal ecosystems present a major challenge for policy makers and citizens all over Indonesia and are pervasive and intense. Land clearing, dredging and site preparation in the coastal watershed can lead to soil erosion and sedimentation. Sediment accumulation leads to the formation of a shallower basin, and has adverse effects on water quality, circulation and the general ecosystem function. The high productivity of marshes, mangroves and coral reefs are of vital importance to the various coastal components. Marshes in rural areas are sites of 
reclamation for community dwellings, plantations and aquaculture farming. Moreover, the relatively calm water of the marsh has become a suitable location for the development of docklands. Population growth and the sprawling of dwelling areas require great volumes of fresh water to be pumped from the ground for human activities, thus resulting in a lowered water table and intrusion of salt water. Conventional farming and fishing practices are afflicted by free market pressure to produce more food for less income, resulting in poverty, the destruction of the environment, neglecting animal welfare and human social justice [1].

During the post Suharto era, the GOI adopted two policies with profound impact on coastal resource use, allocation and distribution: the policy for a decentralized public administration system and the policy for a collective and community based natural resource governance system. A number of objectives underlie the above initiatives. Firstly, there is the need to promote inclusive governance that is responsive to the needs and demands of community user groups. Moreover, during the post Suharto era the national government's aim is to promote devolution and empower the regency government and local user community. As well, there is an urgency to facilitate a more equitable allocation and distribution of Indonesia's natural resources for national stability purposes. This is because by neglecting environmental human rights, the government departments have undermined their own dignity as human beings [2]. Lastly, the national government perceives regional autonomy, decentralization and community based natural resource governance as the trajectory to achieving national integration and enduring sustainability. Nonetheless, decentralization also opens up new challenges and issues, which require going beyond the use of institutionalization and regulatory measures and into the social and cultural dimensions of natural resource governance. Ecosystem degradation produces "winners" and "losers", in which local people are frequently the losers [3]. The roles of environmental group organizations or ENGOs have become more common in bridging the gap between policy and practice, and in lessening the negative implications which government-backed indigenous groups have on participatory democracy in governance and decision making [4].

Even though Indonesia's decentralization policy acknowledges indigenous groups in natural resource governance, the nation's newly decentralized public administration system intensifies coastal resource management issues as provincial and regency government lacks adaptive and socially attuned initiatives for promoting participative engagement and social inclusion. Hence, despite the national government's effort for promoting social inclusion, indigenous groups remain vulnerable to marginalization and dispossession. The once restricted local community has a greater freedom to exploit coastal resources formerly taken away for national development purposes during Suharto's administration. Nonetheless, the presence of structure, more precisely pyramidal structure incorporating the various stakeholders from uphill to downstream, is necessary in governing the country's natural resources as this form of structure provides varying degrees of power, roles and space to different individuals, and this is required for collaboration, coordination and cohesion:

If there is a flat structure with no leader, coordination is impossible. If there is a flat structure with one leader, there are too many individuals for that leader to effectively control. If there is a vertical arrangement with 99 links, nothing gets done by moving from top to bottom. So, in the end, every organization has to adopt a pyramidal structure to allow for coordination and an effective span of control. It is an open question as to how many layers the structure must take, and how many nodes report at each level [5].

As the quote above suggested, it is necessary that the GOI incorporate a pyramidal structure for 'command and control' as well as to provide a close and ongoing feedback loop between policy innovation and implementation innovation. The aim of this article is to portray Indonesia's coastal communities, discuss the challenges and opportunities associated with the GOl's Coastal Community Economic Empowerment Program, and provide suggestions and recommendations for policy makers regarding empowerment and inclusion of marginalized coastal community groups within the country. Through top-down policy evaluation and bottom up ethnomethodological case study of coastal communities in 
Indonesia, the article discusses the GOl's paradigm of community empowerment and contributes to theories relating to empowerment and social inclusion. In addition, origin labels are also important. Origin labels, more specifically Geographical Indications (GIs), allow organised producers to define quality standards and defend their food products' reputation while highlighting their geographical origin and value to consumers [6]. This paper is outlined to include: (i) a depiction of coastal communities in Indonesia along with its issues and challenges, (ii) a description and analysis of the GOl's Coastal Community Economic Empowerment Program, and (iii) suggestions and recommendations for policy improvement.

\section{Method}

The research is a qualitative inquiry using ethnomethodological tools and purposive, snowball sampling. The research was conducted in 2015-2016 in Cilacap, Central Java. Primary data collection was conducted through in-depth interview, participant observation, story-telling and short questionnaires prior to interviewing. Community-engaged research, multispecies research, participatory action research and mapping, and citizen science are some of the methodologies that seek to establish new research design norms in order to coproduce critical, relevant and useable knowledge to address socio-environmental changes [7]. Secondary data took the form of government documents, policy reports, policy analysis, white papers, past research and statistics pertaining to coastal communities in Indonesia. Respondents include government officials, extension officers, community members, local entrepreneurs, cooperative heads and members, community-based credit disbursement/saving and loan institutions, and local NGO workers. Data analysis was conducted through tabulation, categorization, comparison, conceptualization and theorization.

\section{Results and Discussion}

\subsection{Indonesia's coastal communities}

In the year 2000, Indonesia's population reached 210 million, and the population growth rate is 1.8 percent per annum [8]. Approximately 41 million people or $22 \%$ of the population live in or near coastal areas. Half of the 41 million people live in coastal villages and are dependent on local natural resources for their livelihood. Marine related activities account for $20 \%$ of total Gross Domestic Product (GDP), and $19 \%$ of non-oil and gas GDP. Coastal and offshore activities account for $17 \%$ of foreign exchange earnings mainly in oil, gas, fishery and tourism. Moreover, the coastal areas provide employment and income for about 16 million people or $24 \%$ of the national labor force [9].

Research suggests there is a potential for permanent damage to Indonesia's coastal resource base. Resources such as mangroves and sand are over-exploited for wood and construction materials despite their importance for the sustainability of marine and coastal fisheries. Upland erosion and domestic waste damage ecosystems and threaten species of corals and other biological organisms. Moreover, there is a potential for major expansions in aquaculture production and rice farming. These expansions, if not carefully planned and controlled, will destroy valuable ecosystems and natural resources. One of the greatest threats to mangrove swamps in South East Asia has been their conversion into fishponds for aquaculture purposes.

Aquaculture activity is for the commercial production of prawns and milkfish. Aquaculture results in the removal of trees, the dredging of silt and mud, and the construction of dikes. In addition, mangroves and other coastal wetlands are often used for solid waste disposal sites and garbage dumps, leading to land and water pollution through the introduction of toxic substances and pathogens. Moreover, destructive fishing with dynamite and cyanide can damage nurseries and coral reefs in various ways including the burial and destruction of the coral itself. Damage and destruction of the coral reefs lead to a decline in the productivity of harvestable reef resources and a decline in aesthetic value. In addition, damage and destruction of the coral reefs can adversely affect the buffering capacity of the reef, resulting in coastal erosion. It is within the above context that Indonesia's Coastal Community Empowerment Program is implemented within a politically integrated, ecologically sensible and socially cohesive setting. Nonetheless, although the Indonesian civil service is made up of manifold individuals and some are aware of the 
plurality and complexity within community user groups, government officials seem to follow a culture of elitism and political correctness as that evident in the nation's official policies and culture. Moreover, government officials are tied down by many factors such as the regional laws and mandates and the hierarchy and seniority within the bureaucracy. Within the country's coastal communities are (i) fishermen who own boats and equipment used to capture fish in the ocean and lagoons, (ii) fishing crews who work on others' boats earning meager income and living in poverty, (iii) fish merchants who collect and buy fish from fishermen to be resold within and outside the country, (iv) aquaculture farmers growing seaweed and milkfish to be sold locally, and in some instances, (v) property developers, and (vi) proprietors of industries and oil palm plantations.

The coastal areas are rife with conflicts and contentions due to competition over the coastal commons, complex multiple management regimes and inadequate policy environment to enable community sovereignty and deliberative participation beyond utilitarianism and unfettered competition. It is argued that advocacy, brokering and the sustained implementation of indigenous laws for social and ecological protection are essential to avoid adverse incorporation, conflict spiraling and ecological destruction within the country's eco-sensitive coastal areas.

\subsection{Indonesia's coastal community empowerment program: room for improvement}

The Government of Indonesia is currently implementing its Coastal Community Economic Empowerment Program or Pemberdayaan Ekonomi Masyarakat Pesisir (PEMP) to numerous coastal communities in the island of Java, Sulawesi, Sumatra, Kalimantan and Nusa Tenggara. The program is geared to empower local coastal communities through its (i) integrated, holistic vision, (ii) its local-based, participatory method, and (iii) its public-partnership approach. The program consists of three intertwining goals of sustainable development, entrepreneurial growth and welfare improvement for coastal communities. The PEMP program consists of three main activities, namely (i) promoting adequate institutional arrangements at the village and/or neighborhood, district, regency and provincial level for coordination, collaboration and inclusive governance, (ii) establishing a micro-finance scheme within local cooperatives for loan disbursement to community members with little or no interest, and (iii) instilling supervision, mentoring and mediation in times of conflicts. Various constraints emerged in the implementation of Indonesia's PEMP program.

First, with regard to its goal to promote ecological sensibility and sustainable coastal resource use, the program's overemphasis on utilitarianism, regulations and institutional coordinating mechanisms leaves little room for third space to flourish and connect resource users to local coastal resources beyond the façade of utilitarianism and regulations. This third space, when purported into social entities, induce a different perception and sensemaking of one's surrounding environment, provide local coastal resources with new meaning and significance, and can motivate coastal communities to mobilize and protect their immediate coastal environment in critical times. The local-based, participatory method incorporated within the program runs the risk of being sieged by third parties keen on taking advantage of available resources and opportunities whilst relegating the proposed participation mechanisms into mere rubber stamps. Confronted with advancing resource frontiers, local communities increasingly rely on conflict to re-establish order in the face of problematic interdependences [10]. The one-way communication approach with community user groups and the private sectors run the risk of adverse incorporation, marginalization, social dissonance and ecological destruction [11,12]. Moreover, should there be developers and proponents of industries and oil palm plantations within the site, social stratifications emerged, leading to nested power relations and non-inclusive, asymmetrical decision making in relation to the extraction, utilization and distribution of local coastal resources. The resilience of common resources requires their "ownership in the community and their values that can be assessed for compensation purposes and policy and legislation must recognize these [13].

Second, with regard to the program's goal to promote entrepreneurial growth through the micro-credit scheme for increased marine capture and aquaculture farming, differences in sense-making, interests, priorities and perception of risks among relevant 
parties (e.g. government officials, community members, credit lenders, cooperative members) led to fragmentation, dissonance, collusion and corruption of micro-credit funds and resources by local elites. The public-private partnership scheme within the program runs the risk of stalling and/or ceasing in the absence of strong-willed leaders with the authority, reverence and resources to coordinate cross-cutting issues across institutions, jurisdictions and community groups. Detrimental environmental impacts are exacerbated by increasing inequality and neoliberalism understood as a class project of 'accumulation by dispossession' clearly has no need to benefit the rural poor in order to prosper [14]. Moreover, adequate infrastructure and a market-oriented framework is necessary to diversify, transport, market and sell local produce on an extensive scale among large pockets of fishing communities. Nonetheless, the above market capitalist approach to coastal resource management, if not careful, may lead to unfettered commodification and commercialization of local coastal resources due to the uniformly utilitarian meaning embedded within the concept [15,16]. Moreover, gaps and disconnections between community members and the banking system (within the local cooperatives for microfinancing) emerged when installments stalled, collaterals were absent, collusions and corruptions by elites were rife, and community members utilized loans and project money solely for their private profit, hence undermining collective needs and interests and destroying solidarity and social capital for protecting social and ecological commons. Competition may replace collaboration and cooperation, even within the intrinsic communities of practice due to distrust in authorities and mistrust among resource users. Hence, this runs the danger of all hands being on deck, with everyone trying and racing to access and extrapolate local coastal resources for their private profit whilst rendering local wisdom futile and the once pristine ecosystem into open access properties, which are open to grabbing by both external and internal groups of resource users. Social changes and the establishment of democratic institutions go hand in hand and have a positive correlation. Nonetheless, social changes that weaken the established political order make them more vulnerable to challenges. For example, the development of democratic institutions in Indonesia places increased pressure on the government to listen to its constituents [17].

Third, regarding the program's goal to promote social welfare for low-income coastal communities, social and economic stratifications reinforced the ruling elites' authority at the local level and strengthened the nested power relations between capital owners and community members, leading to elite capture. Capture of low-income coastal communities by industrial and government elites are common in Indonesia, whereas self-mobilization of low-income communities through resistance and conformity are fragmented, sparse and lacking in direction, sustenance and leadership. Incorporation into mainstream industrial activities may be adverse, whereas equal participation and equal partnership in economic activities are quite rare. This hinders the 'trickle-down effect', which is perceived as the catalyzing agent for local economic development and empowerment of marginalized communities. Lack of social, economic, psychological and political power among lowincome coastal communities as well as stigmas from outside the vicinities led to their discrimination, marginalization and dispossession. By neglecting environmental human rights, the government departments have undermined their own dignity as human beings [18]. Low-income, laboring coastal communities are highly dependent on the kinship ties and patron-client relations between them and their bourgeoisie/capital owner counterpart. Hence, relations of domination and relations of inequality between them are embraced on the grounds of survival and mutual needs. Hence, devolution of authority and responsibility to the local level cannot function in isolation. The experience of Indonesia suggests that benign community leaders play an important role in enabling local governance structure and promoting the lateral relationships envisioned within Indonesia's policy for devolution, participation and inclusive coastal resource governance and empowerment. In contrast to centralized control, devolving some responsibilities can improve government's access to local knowledge, benefit from community based self-monitoring and enforced trust, gain disaggregated feedback on rule performance, and reduce enforcement costs by improving legitimacy from local participation in rulemaking [19]. 


\section{Conclusion}

Local communities are romanticized to embody egalitarianism, conviviality and the spirit to collectively own and protect common resources. Empowerment is often perceived through a one-way looking glass, comprising of subject-object relations, whereby agency, exerted on passive and reactive objects, are defined, directed, monitored and controlled. It is argued that first and foremost it is very important to validate marginalized members of coastal communities through identification, advocacy and deliberative participation if our effort at 'empowerment' is to succeed. Acknowledging their identity and sovereignty means recognizing and respecting their limited space and resources as well as acting on their terms and capacity. Validating their identity and sovereignty means empowering them psychologically and inducing community members to deliberately participate in protecting and developing the social and ecological commons for benign reasons, which stem from their own consciousness and interests beyond the utilitarianist's narrowly fixated private profit motivation. Creating meaning and accumulating value from natural resources involves multiple economic, cultural, political, and biophysical processes, which occur over different timescales [20]. Instilling civic education for social sensibility and ecological to emerge is no easy matter; it requires ample patience, time and resources. Moreover, institutional intermediaries are required and important for collectivities to perform beyond government mandates and regulations as well as to provide point of reference, standards and benchmarks which can solidify the incentive structure for benign actions. Institutional intermediaries account for the institutional environment in which collective action develops beyond governmental rule and provide standards that instead of negatively affecting the selfgovernance processs of the communities can actually invigorate them [21].

In the light of the need to promote good governance and accountability in empowerment initiatives, there is the need to institute sound intervention approaches. It would be argued that establishing sound intervention policies and programs require securing flexibility and adaptive management capacity through negotiations and brokering. A management outlook that has accepted the inevitability of conflict exacerbates these clashing narratives [22]. Negotiations and brokering are important for responding to dynamic and complex issues in natural resource governance and community empowerment programs. Through negotiations and brokering communication is fostered and alignments of the various user groups are facilitated. This can encourage loyalty to higher levels of governance without undermining devolution and social institutions for natural resource protection within decentralized collectivities.

\section{References}

1. Quinones-Ruiz, X., Can origin labels re-shape relationships along international supply chains?-The case of Café de Colombia. International Journal of the Commons. 2015;9(1):416-439.

2. Gritten, D. Blanket Strategy: A Response of Environmental Groups to the Globalizing Forest Industry. International Journal of the Commons. 2016;4(2):729-757.

3. Acheampong, M. Critical Ecosystem as a Concept in Political Ecology-Developing a Comprehensive Analytical Framework. Journal of Political Ecology. 2020;27(1):192-212.

4. Fabia R, Gallagher J, et al. Efforts to catalogue non-governmental organizations with a role in global burn relief. BURNS. 2020;46(4):804-816.

5. Epstein, R. A. Property Rights: Long and Skinny. International Journal of the Commons, 2020;14(1):567-582.

6. Quinones-Ruiz, X. Can origin labels re-shape relationships along international supply chains? The case of Café de Colombia. International Journal of the Commons. 2015;9(1):416-439.

7. Zanotti, L. Doing Feminist Collaborative Event Ethnography. Journal of Political Ecology. 2020;27(1):961-987. 
8. Badan Pusat Statistik. Statistik Indonesia 1970-2000. 2000. Retrieved February 16, 2004, from www.bps.go.id/sector/population.

9. UNEP. National Report of Indonesia: Preliminary Framework of a Strategic Action Program for the South China Sea, UNEP East Asian Seas Regional Coordination Unit, 1995. pp. 148.

10. Ocakli, B., et al. Shades of Conflict in Kyrgyzstan: National Actor Perceptions and Behaviour in Mining. International Journal of the Commons, 2020;14(1):191-207.

11. Ostrom, E., Ed. Understanding Knowledge as a Commons. From Theory to Practice. Cambridge, MIT Press. 2007.

12. Roos A, Kostakis V, Giotitsas C. Introduction: The Materiality of the Immaterial: ICTs and the Digital Commons. tripleC. 2016;14(6):48-50.

13. Tiah-Bugri, J., et.al. Dynamics of community perceptions, common resources and compensation practices in mining: the case of Newmont Ghana Gold Ltd at Ahafo. International Journal of the Commons, 2018;12(1):15-24.

14. Hewitson, L. et.al. Producing Elephant Commodities. Journal of Political Ecology. $2021 ; 28(1): 1-24$.

15. Plumwood, V. Environmental Culture: The Ecological Crisis of Reason. London, Routledge Publications. 2002.

16. Whiteside, H. Privatizing Canadian government land and real estate: Railroads, reconciliation, and rip-offs. Land Use Policy. 2020;9:104821.

17. Krause, $T$. Reducing deforestation in Colombia while building peace and pursuing business as usual extractivism? Journal of Political Ecology, 2020;(20):1-18.

18. Ahmed, F. Environmental Justice in Bangladesh. Journal of Political Ecology. 2020; 27(1):300-316.

19. Yoder, L. Compelling collective action: Does a shared pollution cap incentivize farmer cooperation to restore water quality? International Journal of the Commons. 2019;13(1):378-399.

20. Fent, A., et.al. Political Ecologies of Time and Temporality in Resource Extraction. Journal of Political Ecology. 2020;27(1):819-829.

21. Navarrete-Cruz, A., et al. Factors Influencing the Development of Rural Producer Organizations in Post-War Settings. The Case of Coffee Growers Associations in Southern Tolima, Colombia. International Journal of the Commons. 2020;14(1):692-713.

22. Boucquey, N. The nature of fisheries governance: narratives of environment, politics, and power and their implications for changing seascapes. Journal of Political Ecology. 2020;27(1):169-189. 